\title{
Kemampuan Literasi Matematis Mahasiswa Melalui Model Problem- Based Learning Menggunakan Klinometer
}

\author{
Adi Asmara ${ }^{1}$, Zachriwan \\ ${ }^{1}$ Universitas Muhammadiyah Bengkulu \\ 1adiasmara@umb.ac.id
}

\begin{tabular}{l}
\hline \hline \multicolumn{1}{c}{ Article Info } \\
\hline Article history: \\
Received Mei $5^{\text {th }}, 2021$ \\
Revised June $20^{\text {th }}, 2021$ \\
Accepted July $22^{\text {th }}, 2021$ \\
\end{tabular}

Keywords:

Literacy;

Problem Based

Learning;

Clinometer

This study aims to determine students' mathematical literacy skills through problem-based learning using a clinometer. This research method is quasi-experimental with the research design used is one group pretestposttest analysis on the initial test obtained results which indicate that the two classes are normally distributed and homogeneous, this means that the two classes are in the same condition or circumstances, namely the ability mathematical literacy so that it can be treated. The final test is also normally distributed and homogeneous, but there is an average difference from the aspect of mathematical literacy skills taught using problem-based learning and conventional learning models. Then the analysis was carried out through the one-way ANOVA hypothesis test, it was obtained that there were significant differences in the two classes. Then proceed with the Scheffe test to see the differences between the two classes, it turns out that there are differences in students' mathematical literacy abilities in the experimental class and the control class. This means that the mathematical literacy ability of the problem-based learning model using a clinometer is higher than the mathematical literacy ability of students using conventional learning models.

\section{Kata Kunci: \\ Literasi; \\ Problem Based \\ Learning; \\ Klinometer}

Abstrak
Penelitian ini bertujuan untuk mengetahui kemampuan
literasi matematis mahasiswa melalui problem-based
learning menggunakan klinometer. Metode penelitian ini
adalah quasi eksperimen dengan desain penelitian yang
digunakan adalah One Group Pretest-Posttest. Analisis
pada tes awal diperoleh hasil yang menunjukkan bahwa
kedua kelas tersebut berdistribusi normal dan homogen,
hal ini berarti kedua kelas tersebut dalam kondisi atau


keadaan yang sama yaitu kemampuan literasi matematis sehingga dapat diberi perlakuan. Pada tes akhir juga berdistribusi normal dan homogen, tetapi terdapat perbedaan rata-rata dari aspek kemampuan literasi matematis yang diajar menggunakan model pembelajaran problem-based learning dan pembelajaran konvensional. Kemudian dilakukan analisis melalui uji hipotesis anava satu jalur, diperoleh terdapat perbedaan yang signifikan pada kedua kelas tersebut. Kemudian dilanjutkan dengan uji Scheffe untuk melihat perbedaan antar dua kelas ternyata diperoleh bahwa terdapat perbedaan kemampuan literasi matematis mahasiswa pada kelas eksperimen dan kelas kontrol. Hal ini berarti kemampuan literasi matematis model pembelajaran problem-based learning dengan menggunakan klinometer lebih tinggi dibandingkan kemampuan literasi matematis mahasiswa dengan model pembelajaran konvensional.

\section{PENDAHULUAN}

Di abad-21 ini literasi matematis itu sangat penting dimiliki oleh setiap insan termasuk mahasiswa. Pengembangan literasi matematis ini menjadi fokus utama di dalam pembelajaran matematika termasuk di perguruan tinggi.

Steen \& Turner (2007) dan OECD (2019) menyatakan bahwa literasi matematika dimaknai sebagai kemampuan untuk merumuskan, menggunakan pengetahuan dan pemahaman matematis secara efektif dalam kehidupan sehari-hari atau literasi matematika adalah kemampuan seseorang individu untuk merumuskan, menggunakan, dan menafsirkan matematika dalam berbagai konteks. Literasi memiliki kaitan erat dengan tuntutan keterampilan membaca. Literasi mencakup bagaimana seseorang mampu memahami informasi secara analitis, kritis, dan reflektif termasuk mendorong kemampuan mengidentifikasi, menentukan, menemukan, mengevaluasi dan menciptakan secara efektif dan terorganisir termasuk kemampuan berkomunikasi (Faizah, dkk., 2016; Wledarti, dkk., 2016). Literasi dapat diartikan sebagai kemampuan mahasiswa untuk membaca tidak hanya buku teks, namun berbagai fenomena dalam kehidupan seharihari sebagai lingkungan belajar secara analitis, kritis, dan reflektif. 
Pengertian lain menyatakan literasi matematika merupakan pengetahuan untuk mengetahui dan menggunakan dasar matematika dalam kehidupan sehari-hari (Ojose, 2011). Dengan demikian, literasi sangat penting bagi mahasiswa untuk menjembatani kegiatan pembelajaran di sekolah atau perguruan tinggi dengan aplikasinya dalam kehidupan sehari- hari

Pembelajaran matematika di perguruan tinggi harus mengkaji atau menghubungkan konteks nyata dalam kehidupan sehari-hari termasuk dalam trigonometri yang dipelajari. Hal ini akan membantu mahasiswa melihat bahwa matematika hadir dalam dunia mahasiswa, termasuk mengapresiasi kebermanfaatan matematika dalam kehidupan. Namun faktanya, trigonometri masih dianggap mata pelajaran sulit dan merupakan sekumpulan rumus yang terlepas dari konteks kehidupan nyata mahasiswa. Hal ini diindikasikan dari sebagian besar mahasiswa menguasai matematika dengan cara menghapal tidak dengan pemahaman, sehingga ketika diberikan soal dengan konteks berbeda mahasiswa mengalami kesulitan dalam menyelesaikannya. Oleh karena itu, perlu dikembangkan pembelajaran yang menjadikan masalah dalam konteks nyata untuk meningkatkan kualitas pembelajaran matematika/trigonometri di perguruan tinggi. Salah satu model pembelajaran yang menggunakan permasalahan dalam konteks nyata adalah model problem-based learning.

Menurut Duch (Shoimin, 2014), problem-based learning adalah model pembelajaran yang bercirikan adanya permasalahan nyata sebagai konteks untuk mahasiswa belajar berpikir kritis dan keterampilan memecahkan masalah serta memperoleh pengetahuan. Sedangkan menurut Finkle dan Torp (Shoimin, 2014) menyatakan bahwa problem-based learning merupakan pengembangan kurikulum dan sistem pengajaran yang mengembangkan secara simultan strategi pemecahan masalah dan dasardasar pengetahuan dan keterampilan dengan menempatkan mahasiswa dalam peran aktif sebagai pemecahan masalah sehari-hari yang tidak terstruktur dengan baik.

Model pembelajaran problem-based learning yang dipakai menggunakan klinometer. Klinometer adalah alat yang digunakan untuk menentukan sudut elevasi dalam mengukur tinggi suatu obyek secara tidak langsung (Widyantini, 2010). 


\section{METODE PENELITIAN}

Jenis penelitian digunakan dalam penelitian adalah quasi eksperimen dengan desain penelitian yang digunakan adalah one group pretestposttest. Populasi dan sampel dalam penelitian ini merupakan seluruh mahasiswa semester I 2020/2021 yang berjumlah 62 orang. Teknik pengumpulan data terdapat 2 macam yaitu 1) metode pengumpulan data, metode yang digunakan untuk mengumpulkan data dalam penelitian ini adalah dengan memberikan tes kemampuan literasi matematis mahasiswa berdasarkan indikator yang sesuai dengan standar kompetensi yang harus dicapai oleh mahasiswa; 2) alat atau instrumen pengumpulan data, tes akan diberikan dalam bentuk soal essai (Aini, 2013: 33).

Tabel 1. Pedoman Penskoran Literasi Matematis Mahasiswa

\begin{tabular}{|c|c|c|c|c|}
\hline No & Aspek yang & Diukur & Skor & Keterangan \\
\hline \multirow[t]{4}{*}{1} & \multirow{4}{*}{\multicolumn{2}{|c|}{$\begin{array}{l}\text { Mampu } \\
\text { Merumuskan } \\
\text { Masalah secara } \\
\text { Matematis }\end{array}$}} & 0 & Tidak menjawab \\
\hline & & & 1 & $\begin{array}{l}\text { Salah merumuskan masalah secara } \\
\text { matematis }\end{array}$ \\
\hline & & & 2 & $\begin{array}{l}\text { Benar dalam merumuskan masalah } \\
\text { secara matematis tetapi tidak lengkap }\end{array}$ \\
\hline & & & 3 & $\begin{array}{l}\text { Benar dalam merumuskan masalah } \\
\text { secara matematis }\end{array}$ \\
\hline \multirow[t]{6}{*}{2} & \multirow{6}{*}{\multicolumn{2}{|c|}{$\begin{array}{l}\text { Mampu } \\
\text { Menggunakan } \\
\text { Konsep, Fakta, } \\
\text { Prosedur, dan } \\
\text { Penalaran dalam } \\
\text { Matematika }\end{array}$}} & \multirow[t]{3}{*}{0} & \multirow{3}{*}{$\begin{array}{l}\text { Tidak ada jawaban, kalaupun ada } \\
\text { menunjukkan tidak memahami konsep } \\
\text { sehingga informasi yang diberikan tidak } \\
\text { berarti apa-apa }\end{array}$} \\
\hline & & & & \\
\hline & & & & \\
\hline & & & 1 & $\begin{array}{l}\text { Menggunakan informasi yang tidak } \\
\text { relevan, gagal mengidentifikasi bagian } \\
\text { yang penting, strategi yang digunakan } \\
\text { tidak tepat, fakta yang diberikan tidak } \\
\text { lengkap, susah diidentifikasi atau tidak } \\
\text { sistematis }\end{array}$ \\
\hline & & & 2 & $\begin{array}{l}\text { Mengidentifikasi beberapa bagian } \\
\text { penting dalam permasalahan tetapi hanya } \\
\text { menunjukkan sedikit pemahaman akan } \\
\text { hubungan kedua tersebut, menunjukkan } \\
\text { fakta dari proses perhitungan tetapi } \\
\text { kurang lengkap dan tidak sistematis }\end{array}$ \\
\hline & & & 3 & $\begin{array}{l}\text { Menggunakan informasi yang relevan, } \\
\text { mengidentifikasi beberapa bagian dan }\end{array}$ \\
\hline
\end{tabular}




\begin{tabular}{|c|c|c|c|}
\hline & & & $\begin{array}{l}\text { menunjukkan general hubungan antara } \\
\text { bagian tersebut, memberikan fakta yang } \\
\text { jelas dalam proses perhitungan dan } \\
\text { sistematis, jawaban mendekati benar }\end{array}$ \\
\hline & & 4 & $\begin{array}{l}\text { Menggunakan informasi yang relevan, } \\
\text { mengidentifikasi semua bagian yang } \\
\text { penting dan menunjukkan general } \\
\text { hubungan antara bagian-bagian tersebut, } \\
\text { memberikan fakta-fakta yang jelas dalam } \\
\text { proses perhitungan dan sistematis, } \\
\text { jawaban benar }\end{array}$ \\
\hline \multirow[t]{5}{*}{3} & \multirow{5}{*}{$\begin{array}{l}\text { Menafsirkan } \\
\text { (interpret) } \\
\text { Matematika } \\
\text { Memecahkan } \\
\text { Masalah }\end{array}$} & 0 & $\begin{array}{l}\text { Salah sama sekali/tidak menjawab sama } \\
\text { sekali }\end{array}$ \\
\hline & & 1 & $\begin{array}{l}\text { Memberikan hasil akhir, tetapi tidak } \\
\text { memberikan alasan }\end{array}$ \\
\hline & & 2 & $\begin{array}{l}\text { Memberikan ilustrasi melalui } \\
\text { model/mengetahui fakta/mengetahui } \\
\text { sifat serta hubungan dari fakta yang } \\
\text { sudah ada, dan dapat menafsirkan tetapi } \\
\text { lemah argumentasinya }\end{array}$ \\
\hline & & 3 & $\begin{array}{l}\text { Memberikan ilustrasi melalui model/ } \\
\text { mengetahui fakta/mengetahui sifat serta } \\
\text { hubungan dari fakta yang ada, dan dapat } \\
\text { memberikan argumentasi yang kuat } \\
\text { untuk menarik suatu kesimpulan }\end{array}$ \\
\hline & & 4 & $\begin{array}{l}\text { Jika benar, lengkap, dan sistematis } \\
\text { menuliskan penyelesaian masalah dari } \\
\text { soal }\end{array}$ \\
\hline
\end{tabular}

Teknik analisis data dalam penelitian ini menggunakan data hasil tes kemampuan pemecahan literasi matematis mahasiswa yang kemudian dianalisis mengunakan Analisis Varian (Anava). Sebelum dilakukan analisis data menggunakan uji anava, dilakukan uji normalitas dan uji homogenitas kemudian dilanjutkan uji hipotesis penelitian dan uji lanjut.

\section{HASIL PENELITIAN DAN PEMBAHASAN}

Analisis pada tes awal diperoleh hasil yang menunjukkan bahwa kedua kelas tersebut berdistribusi normal dan homogen, hal ini berarti kedua kelas tersebut dalam kondisi atau keadaan yang sama yaitu kemampuan literasi matematis sehingga dapat diberi perlakuan. Pada tes 
akhir juga berdistribusi normal dan homogen, tetapi terdapat perbedaan rata-rata dari aspek kemampuan literasi matematis yang diajar menggunakan model pembelajaran problem-based learning dan pembelajaran konvensional.

Perbedaan ini disebabkan karena pada kelas eksperimen model pembelajaran yang digunakan yaitu model pembelajaran problem-based learning adalah dengan langkah mengorientasikan peserta didik terhadap masalah, dosen memotivasi mahasiswa untuk terlibat dalam aktivitas pemecahan masalah nyata yang dipilih dan ditentukan.

Kelas kontrol pembelajaran yang dilakukan adalah pembelajaran konvensional. Pada pembelajaran ini, dosen memberikan materi pembelajaran secara langsung dengan metode ceramah, dosen menjelaskan langsung cara menyelesaikan perbandingan trigonometri pada segitiga siku-siku dan tidak menghubungkan dengan pengetahuan sebelumnya. Sehingga mahasiswa hanya menerima secara pasif tanpa harus mengeluarkan pendapat mereka terlebih dahulu.

Pada data tes akhir, setelah dilakukan analisis melalui uji hipotesis anava satu jalur, diperoleh terdapat perbedaan yang signifikan pada kedua kelas tersebut. Kemudian dilanjutkan dengan uji Scheffe untuk melihat perbedaan antar dua kelas ternyata diperoleh terdapat perbedaan kemampuan literasi matematis mahasiswa pada kelas eksperimen dan kelas kontrol. Hal ini disebabkan karena pada pembelajaran konvensional, materi sepenuhnya disampaikan dosen tanpa dituntut untuk memikirkan darimana asalnya, sehingga mahasiswa tidak memahami langkah-langkah dalam penyelesaian masalah tersebut.

Penjelasan tersebut menunjukkan bahwa kemampuan literasi matematis mahasiswa melalui model pembelajaran problem-based learning dengan menggunakan klinometer lebih tinggi dibandingkan kemampuan literasi matematis mahasiswa dengan model pembelajaran konvensional. 


\section{SIMPULAN}

Kemampuan literasi matematis mahasiswa yang diajarkan melalui model pembelajaran problem-based learning dengan menggunakan klinometer lebih tinggi daripada mahasiswa mendapat pembelajaran konvensional.

\section{DAFTAR PUSTAKA}

Aini, I.N. (2013). Meningkatkan Literasi Matematika Mahasiswa Melalui Pendekatan Keterampilan Proses Matematis: Studi Kuasi Eksperimen pada Mahasiswa Madrasah Tsanawiyah. Tesis pada SPS UPI Bandung: tidak diterbitkan.

Carter, S. (2010). Infusing math with literacy. Reading today in the classroom.

Fatima, Fatia. (2012). Kemampuan Komunikasi Matematis dan Pemecahan Masalah Melalui Problem-Based Learning. http://journal.uny.ac.id.

OECD. (2019). Programme for International Student Assessment (PISA) 2018 Results in Focus- What 15-year-olds know and what they can do with whatthey know. OECD Publishing.

Ojose, B. (2011). Mathematics literacy: Are we a bleto putthe mathematics we learninto everyday use? Journal of Mathematics Education (4)1, pp. 89-100.

Shoimin, Aris. (2014). Model Pembelajaran Inovatif dalam Kurikulum 2013. Jakarta: Ar-ruzz media.

Widyantini., Sigit. (2010). Pemanfaatan Alat Peraga dalam Pembelajaran Matematika SMP Diklat SMP Jenjang Dasar. P4TK Matematika. Yogyakarta. 
84 | Asmara dan Zachriwan: Kemampuan Literasi Matematis Mahasiswa ... 